\title{
Fixed Wage or Share: Contingent Contract Renewal and Skipper Motivation
}

\author{
Pórólfur Matthíasson. ${ }^{1}$
}

\begin{abstract}
Fishermen around the world are usually remunerated with shares. Iceland is no exception in that respect. The fixed wage systems that have been tried out have been short-lived and their utilization limited. The fundamental question asked in this paper is: Why do almost all vessel owners use the same remuneration principles? The answer offered is that the circumstances under which fishing is conducted play a vital role. Surveillance of the conduct of employees is almost impossible. Hence, vessel owners must develop some system for motivating workers and discouraging shirking. It is shown that sharing is better than alternative forms of remuneration in that respect. The production unit is a small platform that is not easily abandoned during a trip. The product of a given trip is well defined. All of these factors help to explain the prevalence of sharing in fisheries. The model of the paper can also shed some light on the on-going conflict between vessel owners and fishermen unions in Iceland in the 1990s.
\end{abstract}

\section{Ágrip}

Sjómönnum vítt og breitt um heiminn er fá yfirleitt hlut af afla eða ágóða sem greiðslu fyrir vinnuframlag sitt. Petta á einnig við um íslenska sjómenn. Fastlaunakerfi hafa verið reynd á Íslandi, en ekki náð fótfestu eða útbreiðslu. Pví er í pessari ritgerð spurt: Hver er ástæða pess að nánast allir útgerðarmenn notast við samskonar grunnreglur til að ákvarða sjómönnum laun? Aðstæður sjómanna samanborið við aðstæður annarra launpega skipta máli. Útgerðarmenn eiga takmarkaða möguleika á að hafa eftirlit með sjómönnum. Pví parf launakerfi sjómanna að vera vinnu hvetjandi. Frá sjónarhóli sjómanna skiptir máli að afurð hverrar veiðiferðar er vel skilgreint. Í greininni er einnig reynt að kasta nokkru ljósi á deilur sjómanna og útgerðarmanna á Íslandi á 10. áratug 20. aldar.

JEL-Categories: D33, J33, J41, L79, Q22

Keywords: Remuneration system in fisheries, contingent renewal, vertically integrated fishing firms

\footnotetext{
${ }^{1}$ Thorolfur Matthiasson is associate professor at the Faculty of Economics and Business Administration, University of Iceland. E-mail: totimatt@hi.is. The author would like to thank Karl Ove Moene, Rögnvaldur Hannesson, Gudmundur Magnússon, Larry Singell, Jean-Pierre Platteau and Thráinn Eggertsson for valuable comments. Furthermore, comments by the editor of this journal and two anonymous referees greatly improved the argument of the paper.
} 


\section{Introduction}

Fishermen around the world are usually remunerated with a share of the catch. The methods used to calculate the share vary from fishery to fishery, from country to country and from time-period to time-period. The Icelandic remuneration system in fisheries is no exception in this respect. The remuneration in Icelandic fisheries has for some time been in the form of sharing catch revenue [see OECD (1966) and Zoeteweij (1956)]. In case of a failed season, the crews are guaranteed a (low and hence almost never activated) minimum income. ${ }^{2}$ Other remuneration rules, including rules with a large fixed wage component or costs sharing, have also been tried out in Icelandic fisheries ${ }^{3}$. For instance, when motors and engines replaced sails and oars, the vessel owners in the Westman Islands offered their crews a fixed wage contract, see Jónsson (1984; Matthiasson (1997). Such fixed wage systems have been short-lived and their utilization limited. Remuneration systems in industries other than fishing show more variety, as varied combinations of fixed wage systems, together with piece rate work, bonuses, and revenue- or profit-sharing systems, are often in use by different firms in the same line of industry, using similar production processes and selling similar products. Hence the following consideration: Why is it that almost all vessel owners use fundamentally the same remuneration method, and why does the implementation vary so widely? Why are the vessel owners remunerating their skippers and crews with fixed wages so very few? Why have the attempts to use other remuneration methods in Icelandic fisheries been so shortlived? One answer to these questions could be that sharing of some form is superior in terms of motivating skippers to work hard. However, it is now well established in the extensive efficiency wage literature that firms can motivate workers to work hard under a fixed wage regime by paying relatively high fixed wages on the condition that low performers are fired. Obviously, such arrangements have not been found to be useful to the same extent in fisheries as in other industries. Furthermore, one could ask, if fixed wages combined with contingent contract renewal does not fare well as a remuneration method in fisheries, why does the vessel owner not rent out the whole vessel to the skipper and/or the crew?

Zoeteweij (1956), Flaaten (1981), Bjøro (1982), Platteau and Nugent (1992), Bergland (1995) and Matthiasson (1999) report the empirical evidence of sharing in fisheries. Flaaten, Anderson, Bergland and Matthiasson discuss the efficiency aspect of the sharing system, in particular the cause or consequence if revenue or cost share parameters differ. Sutinen (1979) discusses the share system as a means to distribute risks between vessel owners and crews. Platteau and Nugent (1992) point out that the actual choice of contract will be influenced by the ability of crews and owners to

\footnotetext{
${ }^{2}$ The minimum income guarantee was conceived in the 1950s. At that time fish export was subject to an export levy that was used to finance various types of funds. The minimum income guarantee fund was one of these. Hence, it can be argued that at the outset the minimum income guarantee was an insurance contract. Later on, as the complex system of funds in the fishing industry was abolished, the financing of the minimum income guarantee was solely the matter of the individual vessel owner. (Source: Benedikt Valsson, Executive Officer of the Union of Maits and Officers on Commercial Vessels).

${ }^{3}$ Differences between the Icelandic system of sharing and those used elsewhere is discussed in Matthiasson (1999).
} 
bear risk, the importance of various types of risk and the ability of the owner to detect and penalize opportunistic behavior.

The institutional arrangement of fisheries in Iceland differs from that of many other fishing communities in some details. As mentioned above, the income guaranteed to a crewmember is so low that it is hardly ever brought into effect except if the vessel is out of operation due to reduced seaworthiness over a prolonged period of time. ${ }^{4}$ Platteau (1989) finds that vertical integration is relatively rare in less developed countries. This contrasts with the fact that more than $2 \beta$ of the value of Icelandic catches comes from vessels operated by integrated fishing-vessel, fishing-plant firms. Lastly, Icelandic crews and Icelandic vessel owners do not share costs. ${ }^{5}$ This also contrasts with praxis in most other fisheries. For a detailed explanation see Matthiasson (1999). ${ }^{6}$

In this paper I develop a model illustrating how a profit-maximizing fishing plant and fishing vessel owner tailors a remuneration package for skippers, keeping

4 The Norwegian sharing system for small and medium-sized vessels, is also characterized in the same way, see Bergland (1995).

5 The share parameters of the bargained agreements between the vessel owners and the fishermen's unions are adjusted when world market price of oil changes. The formula allows the share accruing to fishermen to be lowered when oil prices increase and visa-versa. Hence, as the oil bill of the vessel owners increases some of that cost is shared by the fishermen. The crews, say, will not share a decrease or increase in the oil bill of individual vessel owner due to installation of new equipment. Thus, there is sharing of cost of oil in the macroeconomic sense of the term, not in the microeconomic sense. This paper is only concerned with the microeconomics of sharing.

${ }^{6}$ On a more general level it should be mentioned that economists have a long tradition of investigating the effects of remuneration systems on motivation. Some notable contributions have been made by Leibenstein (1957) who is concerned with the connection between a worker's performance and his well being; Stiglitz (1974), who explains sharecropping as an institution to share risks and provide incentives in situations where the monitoring of worker input is costly; Eswaran and Kotwal (1985), who emphasize the role of managerial ability supplied by landowners; Hayami and Otsuka (1993; Otsuka, Chuma et al. (1993)) who offer a comprehensive overview of the vast literature on sharecropping and conclude that sharecontracts are superior to fixed-wage contracts when landless farmers are risk-averse and that pure rent contracts are superior when farmers are risk-neutral; and Moene (1981) and Lazear (1986), who examine the workings of piece-rate remuneration systems. Following up on the work of Solow (1979) the idea of efficiency wages, which was introduced in Leibenstein (1957) paper, has become more and more popular. Levine $(1987,1989)$ and Moene (1990) compare efficiency wages and profit sharing in a macroeconomic setting. FitzRoy and Kraft (1986) compare share contracts and other forms of remuneration when co-operation between workers is important. Weitzman and Kruse (1990) survey the empirical literature on the productivity enhancing effect of profit sharing. In addition to the literature mentioned above, there is now a growing literature on the optimal franchise contract. Based on the idea of "double moral hazard", Bhattacharyya and Lafontaine (1995) suggest a revenue sharing rule for such contracts. Bai and Tao (1996) suggest that franchised units produce two goods, one that results in local revenue and another that enhances sales at other units. The collective good, "goodwill", will be undersupplied unless the "Head Office" makes it attractive to produce. Hence, Bai and Tao show that offering some units a revenue-sharing contract and other units a fixed-wage-direct-instructions contract may solve the profit-maximizing problem of the head office. 
in mind that skippers can choose another line of work if the prospective income in fisheries is not competitive. The fishing plant fishing vessel owner can choose between an efficiency-wage type fixed-wage system and a revenue-sharing system, or some combination of the two. Renting out vessels to skippers is an obvious fourth alternative. A rent contract will stipulate the economic terms of the arrangement as well as in what condition the vessel is to be when returned to its owner. Hence, a skipper that has rented a vessel will have the power to decide what to fish, when to fish, where to fish, and when and where to unload the catch on shore. The decisions taken by the skipper will not necessarily be consistent with the best interest of the vessel owner if the vessel owner is also a fishing plant owner. A "rent" skipper may choose to unload his catch at a facility that does not belong to the vessel owner or he may choose to unload the catch at the facilities of the vessel owner when fresh fish is plentiful, etc. A skipper on a fixed wage or share contract will be assumed to have less autonomy vis-à-vis the vessel owner than a "rent" skipper. Hence, if a fishing plant/vessel owner is to enjoy possible synergy effects of holding both types of assets, he cannot offer his skippers a rent contract. ${ }^{7}$ Irrespective of which of the three admissible remuneration systems is in use, any skipper who performs poorly will be sacked.

Vessel owners are assumed to be risk-neutral. Hence, one can think of the vessel owner of the model as a firm owned by stockholders that have diversified their assets. The skipper of the model is also assumed to be risk-neutral. Following Sutinen (1979) many authors have assumed that crews are risk-averse. Modeling skippers as risk-neutral in the present set-up serves two purposes. First, if riskneutral agents choose sharing, we know from the existing literature that risk-averse agents will also tend to choose such contracts. Second, even if risk to life and limb has been reduced in modern fisheries, fisheries are still one of the most risk-prone industries. Hence, one could argue that as low-risk occupations have increased their share of occupations in supply, then the least risk-averse persons should be more likely to choose the occupations of crews and skippers. As evidence that the least risk-averse choose the occupation of crew, off-duty crews and former crews are more likely to be involved in accidents than those that have not chosen to be involved in fishing, see Rafnsson and Gunnarsdottir (1992, 1993, 1994). ${ }^{8}$

The paper is organized as follows: The next section contains a theoretical model developed with the particular features of the Icelandic fishery sector in mind. The third section provides a further explanation of the conclusions of the model and some comparative static results. In the fourth section discusses vessel renting and the fifth section concludes the discussion.

\footnotetext{
${ }^{7}$ Note that only about $1 \beta$ of fresh fish brought ashore in Iceland is sold on the individual auction market. Some $60-70 \%$ of the fresh fish is exchanged "directly", i.e., there is some longterm contract between the seller and the buyer of fresh fish. All the big and many of the small freezing plants operate their own vessels.

8 It may also be pointed out that basic elements of contracts for fishermen in many countries, Iceland included, are negotiated not by individual fishermen but by unions. It is not uncommon to assume that unions are less risk-averse than individual union-members, for one example see Booth (1995).
} 


\section{The Model}

Two agents, a vessel owner and a skipper, are for each single period of time, jointly engaged in a productive task (fishing). ${ }^{9}$ The engagement may or may not be continued in the subsequent period. The agents have to negotiate a contract providing for the remuneration of an un-measurable skipper input, i.e. labor. ${ }^{10}$ Labor can be supplied at different levels of effort. If the skipper supplies labor at a low level of effort, the probability is lower that the resulting catch will reach a given level, for any admissible level of catch, than if his supply of effort is high. ${ }^{11}$ The vessel owner supplies capital (under capital we include the vessel, gear, oil, access to necessary facilities ashore, etc). The supply of capital involves knowledge of institutions, investment funds, banks, tax rules, direct and indirect regulations of various kinds, in addition to knowledge of the usefulness of a specific type of gear and vessel, in given waters, for fishing the species of fish intended.

The contracting agents have to choose a remuneration system that is consistent with the requirement that the vessel-owner must be sovereign in matters relating to what to fish and when and where to deliver the catch. In this paper the feasibility of three systems will be considered: the fixed-wage system, the share system and a combination of these two systems. A fourth possibility, that the skipper rents the vessel from the vessel owner will be discussed briefly towards the end of the paper.

Under a fixed-wage system, the vessel-owner pays the skipper a fixed wage at the end of the contract period, independent of the results of the production process, i.e., the catch. If the catch does not reach a certain level (to be defined in more detail shortly), the vessel owner will suspect that the skipper has supplied a low level of effort and will not renew the contract for the following period. Hence, the renewal of the contract is contingent upon satisfactory performance on behalf of the skipper. The vessel owner defines the level of satisfactory performance. Hence, the underlying idea borrows from Bowles and Gintis (1990). A skipper who has been discharged will not be rehired by another vessel owner in the period immediately following, but may or may not be hired in later periods. ${ }^{12}$ When unemployed, the

\footnotetext{
${ }^{9}$ It should be noted that the model does not distinguish between crew interests and skipper interest. Sharing of revenue might serve to bring possibly disparate interest of skipper and crew into alignment. The model does not yield the possibility of analyzing the effect of sharing on crew-as-a-team performance.

${ }^{10}$ More precisely, the vessel owner is partly renting the skipper's human capital consisting of knowledge of fishing spots, knowledge of organizing work on a fishing vessel, knowledge of operating a vessel in rough waters, knowledge of putting the gear to profitable use without destroying it, etc. The vessel owner is partly renting the immediate supply of manual labor necessary for conducting a fishing trip.

${ }^{11}$ More precisely: Denote high level of effort as $H$ and low level of effort as $L$ and assume that effort cannot be supplied in other quantities. Then the statement in the text says that: $\operatorname{Pr}(X=x \mid$ Effort $=H)<\operatorname{Pr}(X=x \mid$ Effort $=L)$ for $x>0$, where the random variable $X$ denotes catch.

${ }_{12}$ Other vessel owners might believe that a fired skipper was incapable of supplying high levels of effort. In that case a fired skipper would never get a new skipper contract. A second possibility is that vessel owners believe a fired skipper to be lazy. It would then depend on their beliefs regarding "rehabilitation" of lazy skippers whether a fired skipper would get another contract or not.
} 
skipper's income will be equal to the unemployment insurance he is entitled to receive. Hence, the fixed-wage system has the elements of an efficiency wage.

Under the share system the skipper and the vessel-owner share the value of the catch. A skipper on share contract may be fired in the same manner as a skipper on a fixed-wage system. ${ }^{13}$

Under a combined fixed-wage and share-wage system, the skipper's remuneration is partly in the form of a fixed wage and partly in the form of a share wage. A skipper on a combined contract may be fired if his performance is not satisfactory.

We shall, in the following paragraphs, consider how the skipper solves the problem of maximizing his lifetime utility, depending on the size of the fixed wage and/or the size of the share rate.

\section{The skipper's problem}

A skipper possesses fishery-specific skills and supplies effort. Both these variables are multi-dimensional and hard to define. ${ }^{14}$ Skipper skills consist, among other things, of knowledge of the area where fishing is conducted, knowledge of where fish go to spawn and feed and if such behavior is influenced by environmental factors, such as the temperature of the water or the salinity of the sea. Fishing effort consists of time and other resources spent on information gathering on- and offshore, time and money spent on searching for fish, time spent on the fishing activity itself, etc.

In what follows, fishing effort will be treated as a one-dimensional variable fully controlled by the skipper. All skippers will be treated as if they commanded the same skills. Fishing is conducted over seasons or periods.

Catches vary stochastically, but expected catch is influenced by the effort supplied by the skipper. Hence, the expected catch of a skipper conditioned on effort supply, $E(X \mid e)$, increases as supply of effort increases. Here $X$ is catch, $E$ is the expectation operator, and $e$ is a measure of skipper effort. ${ }^{15}$

\footnotetext{
${ }^{13}$ Avoiding low catches is of course much more important for a skipper than just avoiding being fired. "Competition among skippers relates first of all to vessels and fishing space, and other factors of obvious relevance for production and success. While the connection between competition and financial success may not always be apparent, as in the case of the fight over the title of "king", prestige is not simply a matter of personal satisfaction or of winning in a competitive game. It is, rather, a matter of central economic importance in determining chances for future success. Prestigious skippers tend to have larger vessels, more sophisticated equipment and sounder financial backing. If the skipper improves his position, he has a chance of commanding a larger vessel, which is an important component in fishing success. If, on the other hand, he has a low position he risks losing his job. One of the Sandgerdi skippers with the lowest prestige was fired at mid-season by his company because "he did not fish enough"." Pálsson (1991), p. 126.

${ }^{14}$ Skipper effects and skills have been discussed to some extent in the literature of the anthropology of fishing. See Acherson (1981), Pálsson (1991), and Thorlindsson (1988). One of the issues debated is whether differences in observed fishing success are the result of luck or acquired or innate skipper-specific skills.

${ }^{15}$ Here, expected catch is supposed to hinge on unobservable environmental factors and unobservable-skipper supplied effort. Vessel owners supply capital equipment. I find it natural to assume that skippers can observe all qualities of the vessel. Hence, I find it more
} 
As $X$ varies stochastically an absent vessel owner will not know if a "poor" realization, $x$ of $X$, is due to bad luck or to low effort on the part of the skipper. If supply of effort reduces skipper utility, and if skippers are paid a flat wage, the following strategy is tempting for the skipper: to minimize his supply of effort, claim the fixed wage and explain any possibly low catch by the erratic nature of the fishing enterprise. The vessel-owner has several solutions to choose between. One is to monitor skipper input on board a fishing vessel by putting controllers on board. That is costly, and probably inefficient, as is best illustrated by the ever-present question of "who should control the controllers". ${ }^{16}$ Bowls and Gintis suggest that employers solve this problem by utilizing the repetitiveness of the exchange between an employee and an employer, or in our case between the skipper and his vessel owner. If an employee does a good job he will get his engagement renewed, if an employer is not satisfied with the quality of the job done or the efficiency with which an employee does a job, the employee's work contract is not renewed. Consequently, renewal of work contract is contingent upon the employee's input of effort. Applied to the present set-up, contingent contract renewal implies that a vessel owner will not re-engage a skipper who brings an unusually small catch to shore.

As stated above, skippers and vessel-owners negotiate a contract for one period at a time. Hence, the skipper's use of effort, the wage or share offered by the vessel owner, and other important variables are fixed for one period ahead each time. The choices made by the vessel owner and the skipper regarding parameters under their control affects the probability distribution for catch. This can be described as follows:

$$
\text { (j. 1) } \quad \operatorname{Pr}(X \leq \hat{x} \mid e=\tilde{e})=F(\hat{x} \mid \tilde{e})
$$

Here $F(\hat{x} \mid \tilde{e})$ is the cumulative probability function associated with the probability that catch is less than $\hat{x}$, conditioned on the event that effort is $\tilde{e}$. I will assume that $F_{e}(\hat{x} \mid \tilde{e})<0$, which implies that the probability of low catch is reduced as effort increases, and that $F_{e e}(\hat{x} \mid \tilde{e})>0$, which implies that an increase in effort has a diminishing effect on the probability of low catch. Furthermore, I assume that $F_{x}(\hat{x} \mid \tilde{e})>0$, which implies that the probability of a "too low" catch is increased as the value $\hat{x}$ increases. Last, I will assume that $F_{e x}(\hat{x} \mid \tilde{e})<0$, so that an increase in the threshold has less influence on the cumulative probability function when effort is high than when effort is low.

At the end of a season, the skipper receives pay (I) from the vessel owner. Instantaneous skipper utility can be written as:

$$
\text { (j. 2) } \quad U=I-g(e)
$$

appropriate to model the situation as a one-sided moral hazard problem, than as a doublesided moral hazard problem. For a review of recent advances in solution of double-sided moral hazard problems, see Bhattacharyya and Lafontaine (1995).

${ }^{16}$ There are many other reasons why it will be inefficient for vessel owners to put controllers on board. One is the question of authority. The skipper is commander-in-chief. What is the status of a controller? Can he command the skipper to keep on fishing if the skipper has decided not to? 
The function $g(e)$ reflects the (moneterized) disutility that the skipper derives from supply of effort. ${ }^{17}$ The effort index, $e$, is normalized so that minimum effort equals zero. ${ }^{18}$ It will be assumed that the first and second derivatives of this function are positive and furthermore that $g(0)=0$.

Skipper income consists either of a share wage, a fixed wage or a combination of the two:

$$
\text { (j. 3) } \quad I=\alpha P X+W
$$

Here the parameter $\alpha$ reflects the skipper's share of revenue, while $W$ is the fixed wage (or non-share wage). The parameters $W$ and $\alpha$ will are to be determined by the vessel owner. It is, however, assumed that $\bar{W}>W \geq 0$ and that $0 \leq \alpha \leq A$, where $A$ is strictly less than unity and $\bar{W}$ is some maximum wage attainable by the skipper. ${ }^{19}$ If the skipper is remunerated by a pure share wage, then $W=0$ and $A \geq \alpha>0$. If the skipper is remunerated by a pure fixed-wage contract, then $W>0$ and $\alpha=0$. The parameter $P$ is the effective ex-vessel price of catch. In the remainder of the paper, it will be normalized to unity unless explicitly stated otherwise. ${ }^{20}$ Obviously, if the skipper is remunerated by a combination of fixed wage and share, then both the share and the fixed-wage parameters are positive. I assume that skippers bring catches ashore at the end of a period, and that share or wage is paid at the beginning of next period. Wage or share is paid irrespective of whether the skipper has his contract renewed or not. Hence the present value of the expected utility of a person starting out as skipper at the beginning of period $t$ (denoted as $V_{t}$ ) can be written as:

$$
\text { (j. 4) } \quad V_{t}=\beta U_{t}+\beta\left[F\left(x^{f} \mid \tilde{e}\right) \hat{V}+\left\{1-F\left(x^{f} \mid \tilde{e}\right)\right\}_{t+1}\right]
$$

Here $U_{t}$ is given by (j. 2) and (j. 3), $\beta=\frac{1}{1+r}$ is the discount factor, $r$ is the skipper's rate of time preference, and $\hat{V}$ is the expected lifetime utility of a skipper losing his position as skipper. The parameter $\hat{V}$ will also be referred to as skipper reservation utility. A skipper will lose his position if his catch is less than the (vessel-ownerdefined) quantity $x .{ }^{21}$ Fired skippers will be unemployed for one period during which they receive unemployment benefits. In a steady state situation we have:

\footnotetext{
${ }^{17}$ The skipper yields effort before receiving payment. It is assumed that this mismatch in timing is taken care of in the form of the disutility function $g(e)$.

${ }^{18}$ The skipper must supply some minimum effort in order to keep the vessel and its crew safe from immediate dangers.

${ }^{19} \mathrm{~A}$ is assumed to be strictly less than 1 in order to take into account that vessel owners have to cover investment costs not explicitly represented in the model. The assumption will be relaxed in Section 4 as the assumptions used in that section will allow investment costs to be recovered by a lump-sum transfer (rent) by the skipper to the vessel owner.

${ }^{20}$ It will also be assumed that the effective ex-vessel price as seen by the skipper is the same as seen by the vessel owner unless when explicitly stated otherwise. For an account of the peculiarities of ex-vessel prices in Iceland consult Matthiasson and Valsson (2000)

${ }^{21}$ The model is formulated as if the skipper knows the cut-off, or threshold value, $x f$, for sure. This needs not to be correct. The vessel owner could of course announce this value. But such
} 


$$
\text { (j. 5) } \quad V_{t}=V_{t+1}=V
$$

Substituting from (j. 5) in (j. 4) and simplifying yields:

$$
V=\beta\left[U+F\left(x^{f} \mid \tilde{e}\right) \hat{V}+\left\{1-F\left(x^{f} \mid \tilde{e}\right)\right\} V\right]=\frac{U+F\left(x^{f} \mid \tilde{e}\right) \hat{V}}{r+F\left(x^{f} \mid \tilde{e}\right)}
$$

A skipper losing his contract will enjoy an expected lifetime utility from the time of dismissal that is equal to his lifetime income in alternative employment, $\hat{V} .{ }^{22}$ All the determinants of skipper lifetime utility are represented in (j. 6). The problem of the skipper is to choose his level of effort so as to maximize the monetarized utility, $V$.

Skippers will supply effort so as to find the optimal solution to following problem:

$$
\text { (j. 7) } \operatorname{Max}_{e \geq 0} V=\frac{U+F\left(x^{f} \mid e\right) \hat{V}}{r+F\left(x^{f} \mid e\right)}=\frac{\alpha E(X \mid e)+W-g(e)+F\left(x^{f} \mid e\right) \hat{V}}{r+F\left(x^{f} \mid e\right)}
$$

The first order condition for solution of (j. 7) is that:

$$
\frac{\partial V}{\partial e}=\frac{\alpha \frac{\partial E(X \mid e)}{\partial e}-g^{\prime}(e)-F_{e}\left(x^{f} \mid e\right)\{V-\hat{V}\}}{r+F\left(x^{f} \mid \tilde{e}\right)}=0
$$

It will be assumed that the second order condition for local maximum is fulfilled. Hence, $D$ defined by (j. 9) must be negative:

$$
D=\alpha \frac{\partial^{2} E(X \mid e)}{\partial e^{2}}-g^{\prime \prime}(e)-F_{e e}\left(x^{f} \mid e\right)\{V-\hat{V}\}
$$

Here $\tilde{e}$ is the optimal level of effort. Condition (j. 8) defines the supply of skipper effort as a function of the vessel-owner-controlled variables $\alpha, \mathrm{W}$ and $x f$.

Condition (j. 8) can be written as:

$$
\text { (j. 10) } g^{\prime}(e)=\alpha \frac{\partial E(X \mid e)}{\partial e}-F_{e}\left(x^{f} \mid e\right)\{V-\hat{V}\}
$$

\footnotetext{
announcements are rare. Hence, the skipper must form expectations about his vessel owners $x f$. Formulating such expectations can be a complicated matter and will be left out here. ${ }^{22}$ The size of will, in general, hinge on the size of the unemployment benefit accruing to unemployed skippers, the probability that a fired skipper will find a new job as skipper, the probability that a fired skipper will find employment in a different line of activity, the amount of pay in such activities, the average time that a fired skipper will have to wait for a new job, etc.
} 
Hence, equation (j. 8) predicts that the skipper will balance the disutility of increasing effort [represented by the term $g^{\prime}(e)$ ] and discounted additional income accruing due to the increased effort. Income accrues to the skipper both directly and indirectly: it accrues directly, as increased effort positively increases revenue, of which the skipper is entitled a share. This effect is represented by the first term on the right side of (j. 10). However, income also increases indirectly, since as effort increases, the likelihood that the catch will be low is reduced. Consequently, the likelihood that the skipper will be fired due to an inadequate catch is also reduced. A skipper who stays employed earns more than a skipper who is fired, as the skipper will loose employment for at least one period and may not be able to find employment of equal profitability in the future. The difference in lifetime income, the skipper rent, is $V-\hat{V}$. This latter effect is represented by the second term on the right side of (j. 10).

Assume, for the sake of illustration, that a skipper is remunerated by a fixed wage only, so that the revenue share is equal to zero. Then, if the expected lifetime earnings of a skipper were equal to his expected lifetime earnings in other occupations (so that $V=\hat{V}$ ), the skipper would only supply minimum of effort. The skipper would not lose in terms of lifetime income if he were fired. Consequently, he would not do anything extra to keep his job as skipper. This result is similar to results derived in ordinary efficiency wage models.

Assume, also for the sake of illustration, that effort is to be kept at a given level, $e^{*}$ say. Equation (j. 10) then shows that effort can be kept at $e^{*}$ with different combinations of size of the skipper rent, $V-\hat{V}$, and the size of the revenue share parameter, $\alpha$. We should note specifically that the lower the share parameter is, the higher the skipper rent must be if effort is to be kept at a constant level.

Implicit derivation of (j. 8) with respect to the share parameter yields:

$$
\frac{\partial e}{\partial \alpha}=\frac{1}{-D}\left\lfloor\frac{\partial E(X \mid \tilde{e})}{\partial e}-\frac{F_{e}\left(x^{f} \mid e\right)}{r+F\left(x^{f} \mid \tilde{e}\right)} E(X \mid \tilde{e})\right\rfloor>0
$$

Thus, skippers will react to any increase in the share parameter by increasing effort. The disutility of increasing effort is compensated for directly with higher income for a given level of catch. This higher income also widens the gap between expected income as skipper and expected income in alternative employment. The cost of losing a job as skipper is thus higher than before. Hence, the increased disutility of supplying more effort is partly paid for by the reduced risk of suffering a loss of income due to dismissal.

Implicit derivation of (j. 8) with respect to the fixed-wage parameters yields:

$$
\frac{\partial e}{\partial W}=\frac{1}{-D}\left[-\frac{F_{e}\left(x^{f} \mid \tilde{e}\right)}{r+F\left(x^{f} \mid \tilde{e}\right)} E(X \mid \tilde{e})\right]>0
$$

Consequently, a skipper will also react to an increase in the fixed-wage parameter by increasing effort. A higher fixed skipper wage widens the gap between expected income as skipper and expected income in alternative employment, thus 
compensating for the increased disutility connected with increased supply of effort. Hence, a lump-sum increase in the fixed wage will affect skipper supply of effect. This result is in line with the conclusions of other efficiency wage models.

We can combine the results given by (j. 11) and (j. 12) in the following way:

$$
\text { (j. 13) } \frac{\partial e}{\partial \alpha} \frac{\alpha}{e}>\frac{\partial e}{\partial W} \frac{W}{e} \frac{\alpha E(X \mid e)}{W}
$$

Hence, if the skipper receives half of his income from the share wage and half from the fixed-wage component of the remuneration contract, so that $\alpha E(X \mid \tilde{e})=W$, then he will react more strongly, in terms of effort supplied, to a $1 \%$ change in the share parameter, than to a $1 \%$ change in the fixed wage. In both cases, increased skipper-income will make it more costly for the skipper to lose his job. But an additional effect is present if the share parameter is increased. The higher share parameter increases the portion of the marginal product accruing to the skipper. Thus, the skipper reacts just like a firm experiencing a higher price for its product, by producing more and demanding more inputs. This last effect is not present if only the fixed-wage component of the remuneration package is increased.

Lastly, note that:

(j. 14) $\left.\frac{\partial e}{\partial x^{f}}=\frac{1}{-D} \mid-F_{e x}\left(x^{f} \mid \tilde{e}\right)[V-\hat{V}]-\frac{F_{e}\left(x^{f} \mid \tilde{e}\right)}{r+F\left(x^{f} \mid \tilde{e}\right)}\left\{V F_{e}\left(x^{f} \mid \tilde{e}\right)-\hat{V} F_{x}\left(x^{f} \mid \tilde{e}\right)\right\}\right]>0$

Given earlier assumptions regarding the sign of the first and the second derivatives of the $F(.,$.$) function, an increase in x f$ will increase the skipper's supply of effort. If the threshold value, $x f$, is increased, it becomes harder for the skipper to gain contract renewal. In the event that the skipper believes that the threshold value, $x$, has been increased, he can restore the situation by increasing his supply of effort.

The problem of the vessel owner

The vessel owner's problem is to design a contract that prescribes the size of the remuneration parameters, $\alpha, W$ and the threshold value of acceptable catch, $x$. The profit of the vessel owner is, of course, affected by the remuneration contract offered and the resulting choice of skipper effort level. The vessel owner must also take into account that fired skippers must be replaced. Hiring and firing of skippers is not without cost; newly hired skippers must be trained and taught, and firing of skippers may involve cost as well. If we assume that the cost of firing and hiring one skipper is $h$, then using the same framework as for the skippers (and ignoring capital costs), and assuming that income accrues at the end of each period, while firing costs accrue at the beginning of a period, and for simplicity that the time preference rate of skippers and vessel owners is identical, we can write the vessel owner's problem as follows: 
s.t.

(j. 15) $\underset{\alpha, W, x^{f}}{\operatorname{Max}} \Pi=\frac{P(1-\alpha) E(X \mid e)-W-h F\left(x^{f} \mid e\right)}{r}$
i) $\quad e=e\left(\alpha, W, x^{f}\right)$
ii) $\quad V \geq \hat{V}$
iii) $\quad \alpha>0$
iv) $\quad W=0$
v) $\quad x^{f}=0$

The constraint (j. 15-i) enters the problem as vessel owners take into account skipper reaction to any change in the remuneration parameter. The second constraint is a skipper participation constraint. Skippers will not participate in fishing if the discounted value of expected utility $(V)$ in fisheries is lower than the discounted value of expected utility in other occupations $(\hat{V})$. The third and the fifth constraints imply that the revenue share and the catch requirement must be non-negative numbers. The fourth constraint implies that the fixed-wage component of the remuneration package must be non-negative. This implies that we do not consider it possible for skippers to pay a fee for the opportunity of taking a vessel to the fishing ground. This could be the result of skippers' union activity, or it could be the result of vessel owner considerations outside of the model as will be discussed later on in this paper. Possibly the effective ex-vessel price of catch, $P$, could differ for vesselowners and skippers. The Kuhn-Tucker conditions for solution of the vessel-owner problem is presented in Matthiasson (1998).

In the next section, we shall consider how the vessel owner determines the remuneration parameters, $W$ and $\alpha$.

\section{Vessel owner decisions}

The vessel owner has to consider that the remuneration parameters affect profits directly and indirectly. Directly, as cet. par., an increase in the remuneration of skipper induces a reduction in the profit of the vessel owner. Indirectly, as increase in the remuneration parameters induces an increase in skipper effort as indicated by (j. 11) and (j. 12).

As indicated before the vessel owner can choose to remunerate the skipper by a flat salary and threat to fire him/her if skipper-performance is below expectations. Alternatively, the vessel owner can remunerate the skipper by a share of the catch. An under performing share-skipper could also expect to be sacked. Which of the two strategies is most economical for the vessel owner is not obvious. Alternatively a mixture of strategies could be economical. In order to shed some light on this question consider the following Lemma and Proposition ${ }^{23}$.

$$
\text { Lemma 1: If } \frac{\partial E(X \mid \tilde{e})}{\partial e}>0 \text { then }\left.\frac{\mathrm{d} \alpha}{\mathrm{d} W}\right|_{\tilde{V}=V\left(\alpha, \tilde{W}, \tilde{x}^{f}\right)}<\left.\frac{\mathrm{d} \alpha}{\mathrm{d} W}\right|_{\tilde{e}=e\left(\alpha, \tilde{W}, \tilde{x}^{f}\right)}<0
$$

\footnotetext{
${ }^{23} \mathrm{I}$ am in debt to an anonymous reviewer for suggesting a line of argument that ultimately resulted in Proposition 1.
} 
Proof: Totally differentiate (j. 6) with respect to $W$ and $\alpha$. Then utilize the first order conditions (j. 8) and (j. 10) and simplify. That yields:

$$
\text { (j. 16) }\left.\frac{\mathrm{d} \alpha}{\mathrm{d} W}\right|_{\tilde{V}=V\left(\tilde{\alpha}, \tilde{W}, \tilde{x}^{f}\right)}=-\frac{1}{E\left(X \mid e\left(\tilde{\alpha}, \tilde{W}, \tilde{x}^{f}\right)\right)}<0
$$

Totally differentiating $\tilde{e}=e\left(\tilde{\alpha}, \tilde{W}, \tilde{x}^{f}\right)$ with respect to $W$ and $\alpha$ yields:

$$
\text { (j. 17) }\left.\frac{\mathrm{d} \alpha}{\mathrm{d} W}\right|_{\tilde{e}=e\left(\alpha, \tilde{W}, \tilde{x}^{f}\right)}=-\frac{\partial e\left(\tilde{\alpha}, \tilde{W}, \tilde{x}^{f}\right) / \partial W}{\partial e\left(\tilde{\alpha}, \tilde{W}, \tilde{x}^{f}\right) / \partial \alpha}
$$

Substitution from (j. 11) and (j. 12) and simplification yields:

$$
\text { (j. 18) }\left.\frac{\mathrm{d} \alpha}{\mathrm{d} W}\right|_{\tilde{e}=e\left(\tilde{\alpha}, \tilde{W}, \tilde{x}^{f}\right)}=-\frac{1}{\frac{\partial E(X \mid e)}{\partial e} \cdot \frac{r+F\left(x^{f} \mid e\right)}{-F_{e}\left(x^{f} \mid e\right)}+E(X \mid e)}<0 \text {. }
$$

It is now easily established that the right hand sides of (j.16) and (j .18) are equal when $\frac{\partial E(X \mid \tilde{e})}{\partial e}=0$. When $\frac{\partial E(X \mid \tilde{e})}{\partial e}>0$ the denominator of $(\mathrm{j} .18)$ is bigger than the denominator of (j. 16) which completes the proof.

We are now ready to proof Proposition 1:

Proposition 1: The vessel owner will set $W$ equal to lowest possible level (zero).

Proof: Assume that the vessel owner adjusts the remuneration parameters $W$ and $\alpha$ simultaneously in such a way that the skipper keeps the level of effort constant and equal to $\tilde{e}$. Then

$$
\text { (j. 19) } \quad \partial e\left(\tilde{\alpha}, \tilde{W}, \tilde{x}^{f}\right) / \partial W \cdot \mathrm{d} W+{ }^{\partial e\left(\tilde{\alpha}, \tilde{W}, \tilde{x}^{f}\right) / \partial \alpha} \cdot \mathrm{d} \alpha=0
$$

Assume that $P=1$. Then, from (j. 6) and (j. 15):

$$
\text { (j. 20) }-\left.\frac{\mathrm{d} \Pi}{\mathrm{d} W}\right|_{e=\tilde{e}}=\left.\frac{r+F\left(\tilde{x}^{f} \mid \tilde{e}\right)}{r} \cdot \frac{\mathrm{d} V}{\mathrm{~d} W}\right|_{e=\tilde{e}}
$$

Totally differentiating (j. 6) with respect to $W$ and $\alpha$, dividing by $d W$ and simplify yields: ): 


$$
\begin{aligned}
\left.\frac{\mathrm{d} V}{\mathrm{~d} W}\right|_{e=\tilde{e}}= & \frac{\partial V\left(\tilde{\alpha}, \tilde{W}, \tilde{x}^{f}\right)}{\partial \alpha}\left[\left.\frac{\mathrm{d} \alpha}{\mathrm{d} W}\right|_{\tilde{e}=e\left(\tilde{\alpha}, \tilde{W}, \tilde{x}^{f}\right)}+\frac{\partial V\left(\tilde{\alpha}, \tilde{W}, \tilde{x}^{f}\right) / \partial W}{\partial V\left(\tilde{\alpha}, \tilde{W}, \tilde{x}^{f}\right) / \partial \alpha}\right] \\
& \left.=\frac{\partial V\left(\tilde{\alpha}, \tilde{W}, \tilde{x}^{f}\right)}{\partial \alpha}\left|\frac{\mathrm{d} \alpha}{\mathrm{d} W}\right|_{\tilde{e}=e\left(\tilde{\alpha}, \tilde{W}, \tilde{x}^{f}\right)}-\left.\frac{\mathrm{d} \alpha}{\mathrm{d} W}\right|_{\tilde{V}=V\left(\tilde{\alpha}, \tilde{W}, \tilde{x}^{f}\right)}\right]
\end{aligned}
$$

Hence, by Lemma 1:

$$
\text { (j. 22) }\left.\frac{\mathrm{d} V}{\mathrm{~d} W}\right|_{e=\tilde{e}}>0 \quad \text { and }\left.\quad \frac{\mathrm{d} \Pi}{\mathrm{d} W}\right|_{e=\tilde{e}}<0
$$

Thus, the vessel owner can increase his profits by lowering the non-share wage. Hence, the constraint in (j. 15, iv)) will be binding.

\section{Adjusting the share parameter}

We have to allow for two different possibilities when considering the vessel owner's decision regarding the remuneration parameter. The first case implies that the skipper participation constraint is not binding, so that the vessel owner can choose the remuneration parameters without considering the level of skipper utility that is implied. The second case covers the situation when the vessel owner has to take the skipper participation decision into account along with considerations of the profits of his own operation.

Adjusting the share parameter when skipper participation constraint is not binding

In this case, the vessel owner can decide the remuneration parameters so as to maximize profits and only has to observe the non-negativity restriction on the share parameter. It should be noted that the vessel owner would not alter his choice of share parameter in the face of changes in skipper reservation utility, for instance, as long as such change does not make the previously chosen share-parameter an inadmissible choice. Changes of exogenous parameters that affect vessel-owner profits will on the other hand affect the choice of a share parameter. Hence, if the relationship between expected catch and skipper supply of effort changes, a change in the share parameter is warranted.

\section{Adjusting the share parameter when skipper participation constraint is binding}

In this case, the vessel owner must take into consideration that he may offer a remuneration package so poor that the skipper finds it more profitable to seek alternative employment. The vessel owner is more restricted in his choice of remuneration parameters here than in the former case.

If the skipper participation constraint is binding, the share parameter will not be altered in the face of changes affecting vessel-owner profits only. But the share parameter will have to be altered in face of changes that affect skipper reservation utility, $\hat{V}$. For instance, a change in the disutility of work or in the size of unemployment benefit or the incidence of unemployment in general will affect the share parameter. 
Furthermore, if the skipper participation constraint is binding, the share parameter will be affected by changes in wages in other parts of the economy as such changes will almost certainly affect the reservation utility.

Changes of the share parameter in the Icelandic fisheries

How does all this relate to the sharing systems actually in use? We can take the Icelandic sharing system as an example. ${ }^{24}$ The revenue share accruing to crews on a given vessel using specific gear and operating with a given number of crew members is represented by $r=a \cdot b$, where $a$ is specific to each category of vessel using specific gear. The parameter $b$ is common for all vessels and all gear and is changed each month according to the price of oil in the world market. The fishery-specific parameters, the a's, seem to be constant for long spells of time. When new gear is introduced, or when new equipment is installed in the vessel, thus reducing the need for labor, a new fishery-specific parameter is negotiated. The universal parameter is constantly being modified, either because of changes in the price of fuel or because a new formula for the parameter is negotiated in collective bargaining agreements.

Hence, the Icelandic system is consistent with our model, given that the skipper participation constraint is not binding. Change of gear or adjustment of the number of crewmembers represents a change in parameters that are exogenous to the vessel owner. This brings a need for the renegotiation of share parameters. On the other hand, if such factors are left unchanged, no change in the share parameter is warranted.

\section{To rent or not to rent a vessel}

Above it has been assumed that skippers do not "receive" a negative $W$. In other words, it has been assumed that skippers do not rent vessels. In unionized economies, such as the Icelandic economy, one can argue that skipper unions are opposed to skippers renting vessels for the following reason: A skipper union might suspect that project renting could depress average skipper income below what the union might find acceptable. Assume that there are more skippers than vessels. Then vessel owners could decide to engage the skipper offering the highest vessel-rent. In equilibrium, skippers would offer to pay so high a rent that the expected utility gain from participating in the fishery would be almost zero. Hence, restricting possible contracts so that skippers are prohibited from offering a rent for taking a fishing vessel to the fishing ground may increase the utility of the skippers participating in the fishery. It is obvious that a single skipper will not be able to establish or enforce such a rule. But a skippers' union is fully capable of doing so.

It was argued in Section 1 of this paper that vessel owners might not rent vessels to skippers, as that would deprive the vessel owner of valuable operational (or managerial) rights. Vessel owners may operate some form of a down-stream activity, freezing plant for instance. Owners of integrated firms may enjoy economies of scope. The owner must have full managerial control for such economies to materialize. Note that a vessel owner will not enjoy such control. For instance, an owner of a skipper-rented vessel can not order that skipper to return to harbor

${ }^{24}$ For description of the Icelandic share system consult Hansdottir (1992) and Matthiasson (1998). 
against the skippers will even if such a move would be very profitable for the vessel owner. In the model of the present paper $^{25}$ the economy of scope would be represented by a higher effective ex-vessel price, $P$, obtainable by the vessel owner than by the skipper. ${ }^{26}$

Assume that effort supplied by a shipper renting a vessel is $\breve{e}$. By arguing in the spirit of Proposition 1 we can conclude that if the non-negativity constraint on $W$ were removed it would be most profitable for the vessel owner to reduce $W$ and increase $\alpha$ until some other constraint is met. That constraint would be that $\alpha \leq 1 .{ }^{27}$ Denote skipper lifetime income gross of rent as $S$ :

$$
\text { (j. 23) } S=\frac{E(X \mid \breve{e})-g(\breve{e})}{r}
$$

Now, the maximum "lifetime" value of vessel-rent that a vessel owner could expect to extract would be $S-V$, as $V$ would be the highest alternative wage that a skipper could expect to enjoy. Hence, the vessel owner will choose not to rent the vessel if $\Pi>S-V$. Now assume that the effective ex-vessel price of catch obtainable by a skipper is 1 per unit of catch but that the vessel owner can obtain an effective exvessel price, $P>1$ for the same unit of catch. Note also that:

$$
\text { (j. 24) } \Pi>S-V \Rightarrow \frac{r+F\left(\tilde{x}^{f} \mid \tilde{e}\right)}{r} \Pi>S-V
$$

Here $\tilde{x}^{f}$ and $\tilde{e}$ are values chosen by share-contracted vessel owner and skipper. The latter inequality represents a sufficient (but not a necessary) condition for share fishing to be more economical than vessel renting from the point of view of the vessel owner. Writing out the latter inequality and simplifying yields:

$$
\frac{[P(1-\tilde{\alpha})+\tilde{\alpha}] E(X \mid \tilde{e})-g(\tilde{e})-h F\left(\tilde{x}^{f} \mid \tilde{e}\right)}{r+F\left(\tilde{x}^{f} \mid \tilde{e}\right)}>\frac{E(X \mid \tilde{e})-g(\tilde{e})}{r}
$$

Note that share fishing would hardly be an option if the net product of share fishing and rental-skipper fishing were identical as rental skipping would avoid the cost incurred by share-fishers due to hiring and firing of skippers. Note furthermore

\footnotetext{
${ }^{25}$ The model assumes risk neutrality on behalf of both the vessel owner and the skipper. The size of the revenue sharing parameter will determine how income risks and operational risks are shared between the vessel owner and the crew. A given share parameter may distribute both risks in correct manner given the nature of the operation. A change in the nature of the operation (introduction of a new management system, say) may upset that equilibrium.

${ }^{26}$ The effective ex-vessel price is not to be confused with the accounting ex-vessel price used when Icelandic vessel owners calculate crew shares. The Icelandic seamen's unions have challenged methods used for fixing the accounting ex-vessel price in integrated Icelandic fishing firms. The effective ex-vessel price is the imputed price per unit of fresh fish in its most valuable use for the firm.

${ }^{27}$ See footnote 16 for justification for assuming that $\alpha>A$.
} 
that a $P$ sufficiently higher than unity could secure the validity of the inequality in (j. 25).

Hence, it seems appropriate to conclude that the bigger the economies of scope of an integrated fishing firm operation the more likely are skippers to be remunerated by shares.

\section{Concluding remarks}

The traditional or "Marshallian" argument against share contracts was based on their static incentive effects. What does the model presented above have to say on this issue? Earlier we asked whether a fixed-wage contract, where contract renewal was contingent upon an acceptable performance in the preceding period could be as good as or even better than a share contract as an incentive instrument. The answer to that question is clearly no. Share contracts outperform fixed wage contracts in an environment where vessel owners fix the remuneration parameters at their own discretion. A vessel owner has the threat of not renewing a contract with a skipper, whether the skipper is on a share contract or a fixed-wage contract. Hence, under either remuneration regime, a vessel owner would have the power to punish a skipper not performing to his satisfaction. Hence, the negative consequences of bad performance are present in both regimes. However, in the case of a share regime, a positive consequence of good performance is added. Good catch implies higher income.

My model predicts that vessel owners will find it more economical to offer a pure share contract than to offer a pure wage contract or a mixed contract. The reason for this result is that skippers on a share contract will work harder at any given level of wage costs accrued by the vessel owner. A hard-working skipper will, on average, supply more catch than one not working as hard. The model is also capable of explaining under which circumstances changes related to vessel-owner profit influence the share ratio, and under which circumstances changes related to skipper-utility influence that ratio. The situation in Iceland is such that changes in vessel-owner profitability influence the development of the share ratios, indicating that skippers are remunerated well in excess of their reservation wage. The model does not explain directly why there are income guarantees in the negotiated share systems in Iceland. During discussion of the optimal effort choice by skippers in Section 2, it was pointed out that low skipper rent and a high revenue share could induce the same skipper effort as low (zero) revenue share and a higher skipper rent. Hence, one of the effects of the revenue share remuneration system, compared with a fixed salary system, is that the employer (the vessel owner) is able to confiscate some of the skipper (employment) rent that would have accrued if unchanged skipper effort were to be induced by a fixed salary remuneration system. Consequently, labor unions in the fishery sector should be reluctant to accept revenue sharing without some form of compensation for the "confiscated" employment rent. The income guarantee may be one way in which this compensation is made.

Fishermen and vessel owners in Iceland have had a hard time reaching a wage agreement in the 1990s. The disagreement seems to involve everything from determination of the ex-vessel price of fish in an integrated vessel-fishing-plantowning firm to how the share parameter should change when new equipment is 
installed to how many hours a crew member should rest before a new trip is initiated. The present model suggests that a solution may be hard to reach. The ex vessel price of fish and the cost of hiring and firing skippers are two important parameters that are exogenous to the model. Both parameters seem to have increased in the past as fish products have been in high demand and as employees have been granted better protection against firing. Both parameters are also likely to increase in the long run. Such changes affect the sharing arrangement. Assume that in the long run competition from would-be skippers forces skippers or skippers unions to accept a fixed level of skipper rent. Vessel owners could offset a given percentage increase in the ex-vessel price, $\mathrm{P}$, by reducing the share parameter by the same percentage. Such a move would leave the skipper participation constraint as well as the first order conditions of the skipper unchanged. ${ }^{28}$ Hence, a higher ex-vessel price of fish is likely to result in increased pressure from the vessel owners to reduce the crew share. A proposal to that effect will certainly be met with hostility on behalf of the fishermen unions. Changes in the cost of hiring and firing do not directly affect the skipper participation constraint. The vessel owner can respond by reducing the firing-threshold value $x$. Such a move would affect the participation constraint of the skipper, making it attractive for the vessel owner to try to reduce the shareparameter somewhat. Hence, if the trend of increase in the ex-vessel price of fish and the cost of hiring and firing continues, crews and skippers can expect a combination of lower share parameter and a reduced probability of firing. Hence, it can be concluded that the vessel owners are likely to continue to keep up the pressure for lower crew shares. The only relief for crews is that the probability of firing may be reduced somewhat in the future.

The question put forward in the introduction of this paper was: Why do vessel owners remunerate their crews by shares? This paper offers a threefold answer: First, because it is profitable for vessel owners. Second, because owners of integrated fishing-plant, fishing-vessel operations may enjoy economies of scope that only can be realized if the vessel-owner has unrestricted managerial control of the operation. And third, because the product and manpower use connected to any given fishing trip is easily defined. The fact that many vessel owners not owning a fishing plant adopt the share system indicates that crews, skippers and vessel owners find this form of remuneration a reliable way to reach their goals regarding income, well being and profit.

\section{References:}

Acherson, J. M. (1981). Anthropology of Fishing. Annual Review of Anthropology, 10, 275-316.

Bai, C-e., \& Tao, Z. (1996). Contract Mix and Ownership. Boston Collage.

Bergland, H. (1995). Sharing the Catch. University of Oslo.

Bhattacharyya, S., \& Lafontaine, F. (1995). Double-sided Moral Hazard and the Nature of Share Contracts. Rand Journal of Economics, 26(4): 761-781.

\footnotetext{
${ }^{28} \mathrm{Assuming}$ that the first order condition is modified to account for the fact that the ex vessel price is not unity as previously stated.
} 
Bjøro, K. (1982). Share Systems in Fishing. University of Cambridge.

Booth, A. L. (1995). The Economics of Trade Unions. Cambridge, UK: Cambridge University Press.

Bowles, S., \& Gintis, H. (1990). Contested Exchange - New Microfoundations for the Political- Economy of Capitalism. Politics E Society 18(2): 165-222.

Eswaran, M., \& Kotwal A. (1985). A Theory of Contractual Structure in Agriculture. American Economic Review 75(3): 352-367.

FitzRoy, F. R., \& Kraft, K. (1986). Profitability and Profit Sharing. Journal of Industrial Economics 35(Dec.): 111-130.

Flaaten, O. (1981). Resource Allocation and Share-Systems in Fish Harvesting Firms, University of British Colombia.

Hansdottir, T. (1992). Hlutaskipti i íslenskum fiskveiðum (Sharing in Icelandic Fisheries), University of Iceland.

Hayami, Y.\& Otsuka, K., (1993). The economics of contract choice : an agrarian perspective. Oxford [England], New York, Clarendon Press ; Oxford University Press.

Jónsson, S. T. (1984). Kaupkerfi við fiskveiðar á Íslandi, University of Iceland, Faculty of Social Sciences.

Lazear, E. P. (1986). Salaries and Piece Rates. Journal of Business 59(3): 405-431.

Leibenstein, H. (1957). The Theory of Underemployment in Backward Economies. Journal of Political Economy 65: 91-103.

Levine, D. (1987). Efficiency Wages in Weitzman's Share Economy. Economics Letters 23: 245-249.

Levine, D. (1989). Efficiency Wages in Weitzman's Share Economy. Industrial Relations 28(3): 321-334.

Matthiasson, T. (1997). Sharing of Revenue in Icelandic Fisheries: A Descriptive Account, Institute for Business Research, University of Iceland.

Matthiasson, T. (1998). Six Essays on Resource Rent Sharing. Oslo, Department of Economics, University of Oslo.

Matthiasson, T. (1999). Cost Sharing and Catch Sharing. Journal of Development Economics, 58(1): 25-44.

Matthiasson, T. \& Valsson, B., (2000). Ex-vessel Price formation in Iceland. Tenth Biennial Conference of the International Institute of Fisheries Economics and Trade, Corvallis, Oregon, International Institute of Fisheries Economics and Trade (IIFET).

Moene, K. O. (1981). Arbeidstempo og akkordsats : interne tilpasninger i en bedrift med interessemotsetninger, Universitetet i Oslo.

Moene, K. O. (1990). Is Profit Sharing a Cure for Unemployment in Less Developed Countries? Journal of Development Economics 33: 89-99.

OECD (1966). Price Systems at the Landing Stage in Fishing Industries of OECD Member Countries. Paris, Organisation for Economic Co-operation and Development. 
Otsuka, K., Chuma, H., et al. (1993). Permanent Labor and Land Tenancy Contracts in Agrarian Economies - an Integrated Analysis. Economica 60(237): 57-77.

Pálsson, G. (1991). Coastal economies, cultural accounts: human ecology and Icelandic discourse. Manchester, Manchester University Press.

Platteau, J. P. (1989). Penetration of Capitalism and Persistence of Small-scale Organizational Forms in Thrid World Fisheries. Development and Change 20(4): 621651.

Platteau, J. P. \& Nugent, J., (1992). Share Contracts and their rationale: Lessons from Marine Fishing. Journal of Development Studies 28(April): 386-422.

Rafnsson, V. \& Gunnarsdottir, H., (1992). Fatal Accidents among Icelandic Seamen 1966-86. British Journal of Industrial Medicine 49(10): 694-699.

Rafnsson, V. \& Gunnarsdottir, H., (1993). Risk of Fatal Accidents Occurring Other Than at Sea among Icelandic Seamen. British Medical Journal 306(6889): 1379-1381.

Rafnsson, V. \& Gunnarsdottir, H., (1994). Dauðaslys sjómanna á sjó og landi (Fatal accidents among seamen occurring at sea and on shore. Læknablaðið, 80: 471-476.

Solow, R. (1979). Another Possible Source of Wage Stickiness. Journal of Macroeconomics 1: 79-82.

Stiglitz, J. E. (1974). Incentives and Risk Sharing in Sharecropping. Review of Economic Studies 21(2): 219-256.

Sutinen, J. G. (1979). Fishermen's Remuneration Systems and Implications for Fisheries Development. Scottish Journal of Political Economy 26(2): 147-162.

Thorlindsson, T. (1988). The Skipper Effect in the Icelandic Herring Fishery. Human Organization 47(3): 199-212.

Weitzman, M. L. \& Kruse, D. L., (1990). Profit Sharing and Productivity. Paying for Productivity. A. S. Blinder. Washington D.C., The Brookings Institution.

Zoeteweij, H. (1956). Fishermen's Remuneration. The Economics of Fisheries. R. Turvey and J. Wiseman. Rome, FAO. 